\title{
Effect of the Active Fraction of Flos Daturae on IFN- $\gamma$ Induced Apoptosis in Immortalized Human Epidermal Keratinocyte Cells (HaCAT)
}

\author{
Ling Tang ${ }^{\sharp 1,2}$, Bing-you Yang ${ }^{\sharp, 2}$, Qiu-hong Wang ${ }^{2}$, Qing Liu ${ }^{3}$ and Hai-xue Kuang*,2
}

${ }^{1}$ Department of Bioengineering, Dalian University, 10 Xuefu Street, Dalian, 116622, P.R. China; ${ }^{2}$ Key Laboratory of
Chinese Materia Medica (Heilongjiang University of Chinese Medicine), Ministry of Education, 24 Heping Road, Har-
bin, 150040 , P.R. China, ${ }^{3}$ Department of Neuropharmacology, National Institute on Drug Dependence, Peking Univer-
sity, 38 Xueyuan Road, Beijing, 100083, P.R. China

\begin{abstract}
The present study is to investigate the effect of the active fraction of Flos Daturae (AF-FD) (dried flower of Datura metel L.) on IFN- $\gamma$ induced apoptosis in a human keratinocyte cell line (HaCAT), which is a widely accepted mimic model of psoriasis. Accordingly, we used MTT and LDH to assay cell viability, FCM and Hoechst 33342 staining to assay cell apoptosis, and Western blotting to assay the expression of keratin 17 (K17). Administration of IFN- $\gamma$ (5-125 $\mathrm{U} / \mathrm{mL}$ ) decreased MTT reduction and increased LDH leakage in a dose-dependent manner. Twenty-five U/mL IFN- $\gamma$ elevated apoptosis significantly. The experimental results showed that AF-FD at the concentrations of 25 and $50 \mu \mathrm{g} / \mathrm{mL}$ alleviated the IFN- $\gamma$-induced inhibition of MTT reduction by $12.58 \%$ and $17.51 \%$, and decreased LDH leakage by $14.47 \%$ and $15.83 \%$, respectively. Through FCM and Hoechst 33342 staining, it was found that AF-FD can lower IFN- $\gamma$ induced apoptosis at the concentrations of $12.5-50 \mu \mathrm{g} / \mathrm{mL}$. The administration of $25 \mu \mathrm{g} / \mathrm{mL}$ AF-FD attenuated the IFN- $\gamma$ induced over-expression of K17 from $206.32 \%$ to $178.83 \%$. The effect of AF-FD on K17 expression may play a key role in protecting HaCAT cells from apoptosis.
\end{abstract}

Keywords: Flos Daturae, Datura metel L., psoriasis, HaCAT cells, cell apoptosis, K17.

\section{INTRODUCTION}

Psoriasis is a chronic hyperplastic inflammatory disease which is well-known for easy relapse and difficulty to treat [1]. It is a T-cell-mediated autoimmune disease [2]. An epitope of keratin 17 (K17) has recently been described as a putative crucial target for psoriasis [3]. Previous investigations indicated that $\mathrm{K} 17$ is undetectable in normal interadnexial epidermis [4], but highly expressed in psoriasis [5]. It has been shown that IFN- $\gamma$ can increase the expression of $\mathrm{K} 17$ in a human keratinocyte cell line (HaCAT) [6, 7]. Some authors used an IFN- $\gamma / \mathrm{K} 17$ loop to explain the positive feedback mechanism between IFN- $\gamma$ activity and K17 expression in psoriasis [8].

Since 1980, calcitriol [9], calcipotriol [10], cyclosporin [11], tretinoin [12], and antibacterials have been used in the treatment of psoriasis, with a variety of major or minor adverse effects. Therefore, over the past few years, research has focused on efforts to find more effective and safe substances to treat psoriasis $[13,14]$. The United States Food and Drug Administration (FDA) approved alefacept [15], efalizumab [16], and etanercept for the treatment of chronic patchy psoriasis [17], with significant improvement in the safety and tolerability compared with traditional treatments.

*Address correspondence to this author at the Key Laboratory of Chinese Materia Medica (Heilongjiang University of Chinese Medicine), Ministry of Education, 24 Heping Road, Harbin, 150040, P.R. China;

Tel: + 86-451-82110803; Fax: + 86-451-82110803;

E-mail: hxkuang@hotmail.com

"These authors contributed equally to this study.
The curative and long-term effects, as well as the adverse effects of these three agents, are still undetermined, however.

Flos Daturae (Datura Flower) is the dried flower of $D a$ tura metel L. (family Solanaceae). It was originally reported in the Compendium of Materia Medica and has been listed in every edition of Chinese Pharmacopoeia. Flos Daturae has a long history of use as a traditional Chinese medicine to treat symptoms of cough, asthma, convulsion, and many others. Data from our recent animal tests have shown that the active fraction of Flos Daturae (AF-FD) can greatly alleviate the condition of psoriasis [18]. There are several clinical trials of Flos Daturae for the treatment of psoriasis ongoing in China.

In previous dermatopathologic research, it has been shown that IFN- $\gamma$ can induce apoptosis in HaCAT cells in vitro [19] and increase the expression of $\mathrm{K} 17$, which makes it a globally acceptable mimic model of psoriasis $[8,19]$. In the present study, we evaluated the IFN- $\gamma$ induced of apoptosis in HaCAT cells and the expression of K17, both in the presence and the absence of AF-FD. The objectives of this study are to: (1) determine the role of AF-FD in protecting against apoptosis and (2) investigate the involvement of AFFD in the expression of K17 and the correlation of K17 and apoptosis.

\section{MATERIALS AND METHODS}

\section{Plant Material}

Flos Daturae (dried flower of Datura metel) was purchased from the Anguo medicine wholesale market (Hebei, China) and authenticated by Prof. Zhengyue Wang of the Department of Pharmacognosy of Heilongjiang University of 
Traditional Chinese Medicine, Harbin, China. The voucher specimen (HB-2003090601) is deposited at the University of Traditional Chinese Medicine.

\section{Chemicals}

The following materials were obtained from the sources indicated: MEM dehydrated medium and non-essential amino acids from GIBCO (Grand Island, NY, USA); FBS from CaiHui Biochemistry Co., Ltd. (Tianjin, China); LDH kit from BHKT Clinical Reagent Co., Ltd. (Beijing, China); Sodium pyruvate from BoDi Chemical Engineering Co., Ltd. (Tianjin, China); IFN- $\gamma$, MTT, PI, SDS, acrylamide and trypsin from Sigma (USA); RNase A and Hoechst 33342 from DingGuo Biotechnology Co., Ltd. (Beijing, China); Mouse anti-cytokeratin 17 multiclonal antibody and mouse anti- $\beta$-actin monoclonal antibody from Santa Cruz Biotechnology (Santa Cruz, CA, USA); Horseradish peroxidaseconjugated goat anti-mouse HPR-IgG from Zhongshan Goldenbridge Biotechnology Co., Ltd. (Beijing, China); BSA from Sino-American Biotechnology Company (Henan, China); ECL Advanced Western blotting detection kit from Amersham Biosciences (UK). All other chemicals used were of the highest purity that is commercially available domestically.

\section{Preparation of the Active Fraction of Flos Daturae (AF- FD)}

The preparation method was described in a previous publication [20]. Briefly, Flos Daturae was percolated by $70 \%$ EtOH. Sequentially, the EtOH extract of Flos Daturae was soaked in $0.1 \% \mathrm{HCl}$, and then the acid solution was applied to a $732(001 \times 7)$ Cation Exchange Resin column chromatograph. The effluent was fractioned by AB-8 Macroporous Adsorptive Column Chromatography, eluting with $\mathrm{H}_{2} \mathrm{O}, 50 \%$ and $95 \%$ EtOH- $\mathrm{H}_{2} \mathrm{O}$ to give three fractions. The $50 \% \mathrm{EtOH}$ fraction was AF-FD, which accounted for $0.15 \%$ of the crude drug. Compound 3-O- $\beta$-D-glucopyrano$\operatorname{side}(1 \rightarrow 2)-\beta$-D-glucopyranosyl, $7-O-\alpha$-L-rham-nopyranosyl kaempferol (1) served as a reference substance. The chemical reference and total flavonoids in the active fraction of Flos Daturae were quantified in ten replicates by highperformance liquid chromatography and the colorimetric method. More than $53 \%$ of the AF-FD was FC-FD. Thus, flavonoids are responsible for the bioactivity of Flos $\mathrm{Da}$ turae.

The AF-FD was then prepared with aseptic $0.1 \%$ DMSO. Our preliminary experimental results indicated that $0.1 \%$ DMSO does not damage HaCAT cells.

\section{Cell Culture and Treatment}

The human keratinocyte cell line (HaCAT) [21] was obtained from the China Center for Type Culture Collection (CCTCC) (Wuhan, China) and the HaCAT cells were routinely grown in MEM (GIBCO) supplemented with $10 \%$ heat-inactivated FBS, $1 \%$ non-essential amino acids (GIBCO), penicillin $(100 \mathrm{U} / \mathrm{mL})$ and streptomycin (100 $\mathrm{ng} / \mathrm{mL}$ ) under a humidified atmosphere containing 5\% $\mathrm{CO}_{2}$ at $37^{\circ} \mathrm{C}$. They were subcultured every $2 \sim 3$ days. Cells harvested by $0.25 \%$ trypsinization were stained for viability with trypan blue and counted in a hemacytometer. Counts of viable attached cells under subconfluent growth conditions were taken as a parameter for cell proliferation.
For all experiments $48 \mathrm{~h}$ cell cultures with MEM were used. IFN- $\gamma$ was added into the nutrient solution, with or without AF-FD, for $72 \mathrm{~h}$. All experiments contained an appropriate solvent control group.

\section{Analysis of Cell Viability}

The MTT assay and LDH assay were used to assess cell viability.

\section{MTT Assay}

Cell viability was determined by measuring the mitochondrial dehydrogenase activity (MDHA) using the MTT assay [22]. HaCAT cells were inoculated in 24-well plates at the concentration of $2 \times 10^{5}$ cells per $\mathrm{mL}$. After the cells were cultured for $48 \mathrm{~h}$ into a subconfluent state, the medium containing various concentrations of $\operatorname{IFN}-\gamma(5,25$, and 125 $\mathrm{U} / \mathrm{mL}$ ) was added to each well and incubated for $72 \mathrm{~h}$. Then $50 \mu \mathrm{L}$ MTT solution $(0.5 \mathrm{mg} / \mathrm{mL})$ was added to each well and the plate was incubated at $37^{\circ} \mathrm{C}$ for $4 \mathrm{~h}$. Formazan crystals produced by MDHA in viable cells were dissolved by adding $2 \mathrm{~mL}$ acidic isopropanol at room temperature. Then, after vigorous shaking, the O.D of the resulting solution was measured spectrophotometrically at $570 \mathrm{~nm}$. The cell survival rate was calculated as follows: $(\%)=$ treated/average of control $\times 100 \%$.

To examine the effects of AF-FD on the IFN- $\gamma$ induced inhibition of MTT reduction, IFN- $\gamma(25 \mathrm{U} / \mathrm{mL})$ and AF-FD $(12.5,25.0$, and $50.0 \mu \mathrm{g} / \mathrm{mL})$ were added to HaCAT cells in a subconfluent state at the same time. After $72 \mathrm{~h}$ incubation, corpuscular viability was assessed by the MTT assay.

\section{LDH Assay}

The activity of LDH, a stable cytosolic enzyme that is released upon the increase in plasma membrane permeability, was determined using a commercial test kit (Beijing BHKT Clinical Reagent Co., Ltd.) [23]. After the cells were grown for $48 \mathrm{~h}$ to a subconfluent state, HaCAT keratinocytes were incubated with various concentration of $\operatorname{IFN}-\gamma(5,25$, and $125 \mathrm{U} / \mathrm{mL}$ ) for $72 \mathrm{~h}$. Then the LDH activity was spectrophotometrically determined by NADH disappearance rate at $440 \mathrm{~nm}$ as a detection wavelength in the extracellular and intrastitial medium, respectively. The results were expressed as $\mathrm{LDH}$ released $(\%)=($ extracellular activity $) /($ extracellular activity + intrastitial activity) $\times 100 \%$.

To examine the effects of AF-FD on LDH leakage induced by IFN- $\gamma$, IFN- $\gamma(25 \mathrm{U} / \mathrm{mL})$ and AF-FD $(12.5,25.0$, $50.0 \mu \mathrm{g} / \mathrm{mL})$, using DMSO as a solvent at a final concentration of $0.1 \%$, were sequentially added to the HaCAT cells at subconfluent state followed by incubation for $72 \mathrm{~h}$. LDH activity was then spectrophotometrically determined.

\section{Assessment of Apoptosis}

This procedure was performed as previously described [24]. Briefly, after using $0.25 \%$ trypsinization for each group, harvested cells at a concentration of $1 \times 10^{6}$ cells were washed twice with $2.5 \mathrm{~mL}$ of $0.1 \mathrm{M}$ PBS. Then, cells were washed by centrifugation at $800 \mathrm{rpm}$ for $6 \mathrm{~min}$. Later, with the supernatant $(\mathrm{SN})$ discarded, $1 \mathrm{~mL}$ of PBS and $5 \mathrm{~mL}$ of ice-cold $70 \%$ ethanol $/ \mathrm{H}_{2} \mathrm{O}$ were added into the sample tube while it was in vortex. Fixation was allowed to proceed at $4^{\circ} \mathrm{C}$ overnight. The cells were then washed and incubated 
with $50 \mu \mathrm{L}$ of $10 \mathrm{mg} / \mathrm{mL}$ RNAse for $30 \mathrm{~min}$ at $37^{\circ} \mathrm{C}$, then placed on ice. Harvested cells were stained with $50 \mu \mathrm{g} / \mathrm{mL}$ propidium iodide in PBS. After $30 \mathrm{~min}$, cell apoptosis was analyzed by FACSCulibur flow cytometry (Becton Dickinson). Relative cell distribution was calculated using Multicycle software (Phoenix Flow Systems, USA).

In order to confirm the accuracy of the results, Hochest 33342 staining was implemented. After various treatments (see above), HaCAT keratinocytes were incubated for $72 \mathrm{~h}$ at $37^{\circ} \mathrm{C}$. The cells were washed with PBS and fixed with $4 \%$ paraformaldehyde for $10 \mathrm{~min}$ in the dark at room temperature. Then, with the fixative solution discarded, the nuclei were stained with Hochest $33342(15 \mu \mathrm{g} / \mathrm{mL}$, Sigma, USA) for $15 \mathrm{~min}$ at $37^{\circ} \mathrm{C}$ [25].

Samples were observed using a LeicaDMIRE2 fluorescent microscope (Leica, Germany). The rate of apoptosis was calculated using the average value of three experiments, apoptotic rate $(\%)=$ apoptotic cells/total cells $\times 100 \%$.

\section{Assay for the Expression of K 17}

Western blotting was used to detect the expression of cytokeratin K 17. Methodically, the cell culture and drug treatments were the same as described above. Cell cultures were washed twice with $10 \mathrm{~mL}$ ice-cold PBS and lysed in $150 \mu \mathrm{L}$ lysis buffer $(10 \mathrm{mM} / \mathrm{L}$ Tris- $\mathrm{HCl} \mathrm{pH} 8.0,1 \mathrm{mM} / \mathrm{L}$ EDTA, $150 \mathrm{mM} / \mathrm{L} \mathrm{NaCl,1 \%} \mathrm{NP-40,1} \mathrm{mM/L} \mathrm{PMSF,1 \%} \mathrm{SDS)}$ over ice for $20 \mathrm{~min}$. The lysates were centrifuged at $12000 \mathrm{~g}$ for $15 \mathrm{~min}$ at $4^{\circ} \mathrm{C}$ and clear supernatants were collected. The protein content of the supernatants was determined with the Bradford method and adjusted to the same concentration with lysis buffer. The cellular lysates $(20 \mu \mathrm{g}$ protein) were separated by $10 \%$ SDS-PAGE electrophoresis [26], then transferred to a nitrocellulose membrane. The membrane was incubated with $\mathrm{PBS} / 5 \%$ non-fat dried milk overnight at $4{ }^{\circ} \mathrm{C}$ to block nonspecific binding. The membrane was then incubated with a mouse anti-cytokeratin 17 multiclonal antibody $(1: 800, \mathrm{ZM}-0072)$ and a mouse anti- $\beta$-actin monoclonal antibody $(1: 5,000)$ for $1 \mathrm{~h}$ at room temperature in the dark. Detection was accomplished with a horseradish peroxidaseconjugated goat anti-mouse HPR-IgG (1:2,000, ZF-0312) for $1 \mathrm{~h}$, and visualized using a ECL Advanced Western blotting detection kit with X-ray film exposure. Blot density, indicative of the level of cytokeratin K 17 and $\beta$-actin, was analyzed with the software NIH Image (ver. 1.63).

\section{Statistical Analysis}

The data are expressed as mean \pm S.E. Statistical analyses were performed by one-way ANOVA and a post hoc LSD test. $P$-values less than 0.05 were considered statistically significant.

\section{RESULTS}

Determination of the Reference Substance and Total Flavonoids in AF-FD

\section{Isolation and Identification of the Reference Substance in $A F-F D$}

The AF-FD was purified by chromatography on a silica gel column with $\mathrm{CHCl}_{3}-\mathrm{CH}_{3} \mathrm{OH}$ as the eluting solvent. The fraction eluted with $\mathrm{CHCl}_{3}-\mathrm{CH}_{3} \mathrm{OH}$ (3:1) was separated by
Sephadex LH-20 column chromatography eluting with $\mathrm{CH}_{3} \mathrm{OH}-\mathrm{H}_{2} \mathrm{O}$. Then the distillation cut was eluted through $\mathrm{C}_{18}$ reverse-phase silica gel and semipreparative HPLC (ODS column, phenomenex, $8 \mu \mathrm{m}$ particle size, $250 \times 10 \mathrm{~mm}$, eluted with $55 \% \mathrm{MeOH}$ at $2.5 \mathrm{~mL} / \mathrm{min}$, detection with UV $254 \mathrm{~nm})$, to isolate $3-O-\beta$-D-glucopyranoside $(1 \rightarrow 2)-\beta$-Dglucopyranosyl, 7- $O$ - $\alpha$-L-rhamnopyranosyl kaempferol (1), a yellow powder, as the reference substance.

$\mathrm{FAB}^{+}$-MS analysis (JMS-DX302) of Compound $\mathbf{1}$ showed the quasi-molecular ion at $\mathrm{m} / \mathrm{z} 757.02[\mathrm{M}+\mathrm{H}]^{+}$, which corresponded to the molecular formula $\mathrm{C}_{33} \mathrm{H}_{42} \mathrm{O}_{20}$. Maximum absorption bands at 258( $\varepsilon$ 20000) and $358(\varepsilon$ $16000) \mathrm{nm}$ in $\mathrm{MeOH}$ suggested that 1 was a flavonol compound. The ${ }^{1} \mathrm{H}-\mathrm{NMR}$ spectrum indicated 6 aromatic protons at $\delta 6.72(1 \mathrm{H}, \mathrm{d}, J=2.5 \mathrm{~Hz}), \delta 6.42(1 \mathrm{H}, \mathrm{d}, J=2.5 \mathrm{~Hz}), \delta 8.04$ $(2 \mathrm{H}, \mathrm{d}, J=8.7 \mathrm{~Hz})$, and $\delta 6.90(2 \mathrm{H}, \mathrm{d}, J=8.7 \mathrm{~Hz})$ assigned to the aglycone moiety of a kaempferol skeleton. Three anomeric signals in ${ }^{1} \mathrm{H}-\mathrm{NMR}(\delta 5.411 \mathrm{H}, \mathrm{d}, J=7.5 \mathrm{~Hz} ; \delta 4.77$ $1 \mathrm{H}, \mathrm{d}, J=7.3 \mathrm{~Hz} ; \delta 5.561 \mathrm{H}, \mathrm{d}, J=2.5 \mathrm{~Hz})$ and ${ }^{13} \mathrm{C}-\mathrm{NMR}(\delta$ $98.6,103.1,99.0)$ suggested the existence of three sugar moieties, one of which was assigned to the anomeric proton of the rhamnose residue from the correlation according to methyl protons at $\delta 1.24\left(3 \mathrm{H}, \mathrm{d}, J=6.0 \mathrm{H}_{\mathrm{Z}}\right)$, the other two of which were assigned to the anomeric proton of the glucose residue from the correlation. All the ${ }^{13} \mathrm{C}-\mathrm{NMR}$ signals were assigned by H-H COSY, HSQC and HMBC (Table 1). The sugar chain was determined to be located at C-3 in that the anomeric proton signal of the glucose residue $(\delta 5.41,1 \mathrm{H}, \mathrm{d}$, $J=7.5 \mathrm{~Hz})$ correlated with $\mathrm{C}-3$ of the aglycone $\left(\delta_{\mathrm{c}} 98.6\right)$ in the HMBC data. The sugar chain was determined to be located at $\mathrm{C}-7$ in that the anomeric proton signal of the rhamnose residue $(\delta 5.56,1 \mathrm{H}, \mathrm{d}, J=2.5 \mathrm{~Hz})$ correlated with $\mathrm{C}-7$ of the aglycone $\left(\delta_{\mathrm{c}} 99.0\right)$ in the HMBC data. Interglycosidic linkages were determined on the basis of $\operatorname{HMBC}(2$ " of Glu' with C-1"' of glu") (Fig. 1). The anomeric protons at $\delta 5.41(1 \mathrm{H}, \mathrm{d}$, $J=7.5 \mathrm{~Hz})$ and $4.77(1 \mathrm{H}, \mathrm{d}, J=7.3 \mathrm{~Hz})$ indicated the $\beta$ configuration for two glucopyranosyl moiety, but at $\delta 5.56$ $(1 \mathrm{H}, \mathrm{d}, J=2.5 \mathrm{~Hz})$ indicated the $\alpha$-configuration for the rhamnopyranosyl moiety. Compound $\mathbf{1}$ was identified by comparison with the spectroscopic data reported in the literature (Markham et al., 1978). Thus, the structure of 1 was determined to be $3-O-\beta$-D-glucopyranoside $(1 \rightarrow 2)-\beta$-Dglucopyranosyl, 7-O- $\alpha$-L- rhamnopyranosyl kaempferol.

\section{Quantitation of Reference Substance in AF-FD}

The amount of reference substance in the active fraction of Flos Daturae was determined by LC-2010 High Performance Liquid Chromatography using a C18 column ( $5 \mu \mathrm{m}, 4.6$ $\mathrm{mm} \times 250 \mathrm{~mm})$. The column temperature was set at $30^{\circ} \mathrm{C}$, and detection was carried out at $268 \mathrm{~nm}$. The flow rate was 1 $\mathrm{mL} / \mathrm{min}$. The mobile phase consisted of $2 \% \mathrm{CH}_{3} \mathrm{OH}$ in sodium acetate buffer solution $(1,000 \mathrm{~mL}$ buffer solution containing $20.4 \mathrm{~g}$ sodium acetate and $80 \mathrm{~mL}$ acetic acid, $\mathrm{pH}$ 3.69). The Theoretical Plate Number was $\geq 4,000$. Determined under these conditions, the retention time of the reference substance was $37.967 \mathrm{~min}$.

The standard curve method was used to assay the content of reference substance, which ranged from 3.0 to $4.2 \%$ in ten replicate of sample, with an average 3.4\% (Table 2 and Fig. 2). 
Table 1. ${ }^{13} \mathrm{C}-\mathrm{NMR}$ Data of Compound 1 in DMSO- $\mathrm{d}_{6}$. The ${ }^{13} \mathrm{C}-\mathrm{NMR}$ Spectra were Obtained with a Bruker-ARX-500 Spectrometer (125 MHz for $\left.{ }^{13} \mathrm{C}\right)$ in DMSO- $\mathrm{d}_{6}$. Chemical Shifts $(\delta)(\mathrm{ppm})$ Relative to TMS as an Internal Standard

\begin{tabular}{|c|c|c|c|c|}
\hline \multirow[b]{2}{*}{ Position } & \multicolumn{4}{|c|}{$\delta c$} \\
\hline & Kaempferol & $\begin{array}{l}\text { 3-O-glc-7-O-rha } \\
\text { Kaempferol }\end{array}$ & $\begin{array}{l}\text { 3-O-glc }(1 \rightarrow 2) \text { glc } \\
\text { Kaempferol }\end{array}$ & Compound 1 \\
\hline 2 & 146.1 & 156.0 & 156.4 & 156.4 \\
\hline 3 & 135.5 & 133.6 & 133.1 & 133.5 \\
\hline 4 & 175.7 & 177.5 & 177.5 & 178.2 \\
\hline 5 & 156.0 & 160.9 & 161.2 & 161.1 \\
\hline 6 & 98.2 & 99.5 & 98.6 & 99.3 \\
\hline 7 & 163.8 & 161.8 & 164.0 & 161.8 \\
\hline 8 & 93.4 & 94.6 & 93.6 & 94.0 \\
\hline 9 & 160.5 & 157.2 & 156.4 & 157.9 \\
\hline 10 & 102.9 & 105.7 & 104.2 & 105.8 \\
\hline $1^{\prime}$ & 121.6 & 120.7 & 121.1 & 121.0 \\
\hline $2^{\prime}$ & 129.3 & 130.7 & 130.6 & 130.9 \\
\hline $3^{\prime}$ & 115.3 & 115.0 & 115.2 & 114.8 \\
\hline $4^{\prime}$ & 159.0 & 160.1 & 160.0 & 159.7 \\
\hline $5^{\prime}$ & 115.3 & 115.1 & 115.2 & 114.8 \\
\hline $6^{\prime}$ & 129.3 & 130.7 & 130.6 & 130.9 \\
\hline 3-O-glc1" & & 101.3 & 98.6 & 98.6 \\
\hline $2 "$ & & 74.1 & 80.9 & 80.9 \\
\hline $3^{\prime \prime}$ & & 76.4 & 76.6 & 76.6 \\
\hline $4^{\prime \prime}$ & & 70.0 & 70.0 & 69.6 \\
\hline $5 "$ & & 74.1 & 76.6 & 76.3 \\
\hline $6^{\prime \prime}$ & & 62.9 & 61.0 & 60.9 \\
\hline glc1"' & & & 103.6 & 103.1 \\
\hline $2^{\prime \prime \prime}$ & & & 74.3 & 74.0 \\
\hline $3^{\prime \prime \prime}$ & & & 76.7 & 76.5 \\
\hline $44^{\prime \prime \prime}$ & & & 70.5 & 69.4 \\
\hline $5^{\prime \prime \prime}$ & & & 76.7 & 76.5 \\
\hline 6"' & & & 61.4 & 60.8 \\
\hline 7-O-rha1"'"' & & 98.7 & & 99.0 \\
\hline $2^{\prime \prime \prime \prime \prime}$ & & 70.0 & & 70.4 \\
\hline $3^{\prime \prime \prime \prime \prime}$ & & 70.5 & & 70.0 \\
\hline $4^{\prime \prime \prime \prime \prime}$ & & 71.8 & & 72.0 \\
\hline $5^{\prime \prime \prime \prime \prime}$ & & 69.8 & & 69.6 \\
\hline $6^{\prime \prime \prime \prime \prime}$ & & 17.7 & & 16.5 \\
\hline
\end{tabular}

\section{Quantitation of Total Flavonoids in AF-FD}

The amount of total flavonoids in the active fraction of Flos Daturae was determined using a UV-1601 Spectrophotometer. Maximum absorption was observed at $268 \mathrm{~nm}$, so it was used as the detection wavelength.

The data from ten replicate of sample were analyzed by the external standard method. The content of total flavonoids ranged from 54.0 to $57.2 \%$, with an average of $55.4 \%$ (Table 2 and Fig. 3).

The Active Fraction of Flos Daturae (AF-FD) Alleviated the Inhibition of MTT Reduction Induced by IFN- $\gamma$ in HaCAT Cells

HaCAT cells were incubated in 24-well plates for $48 \mathrm{~h}$ to a subconfluent state. Then $5-125 \mathrm{U} / \mathrm{mL}$ IFN- $\gamma$ was added 


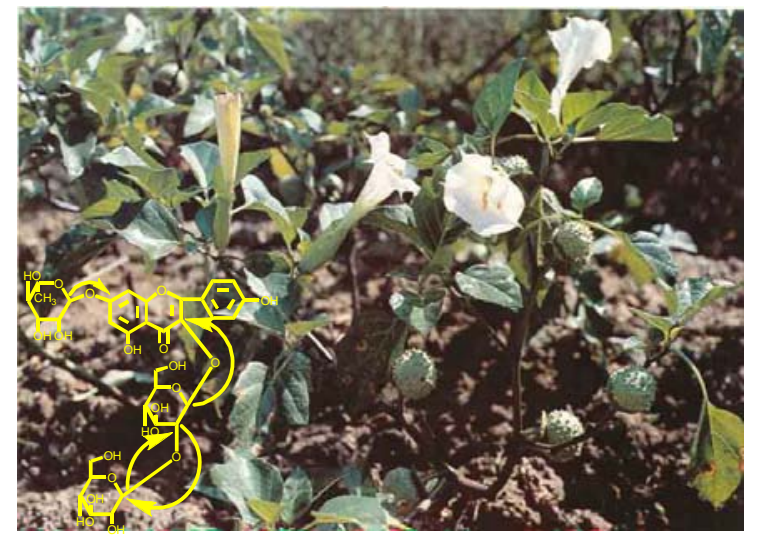

Fig. (1). 3- $O-\beta$-D-glucopyranoside $(1 \rightarrow 2)-\beta$-D-glucopyranos, 7- $O$ $\alpha$-L-rhamnopyranosyl kaempferol (1) isolated from active fraction of Flos Daturae (AF-FD), the dried flower of Datura metel L. (photo).

into different groups of wells for $72 \mathrm{~h}$, and the MTT reduction level of each group was obtained. All data were normalized to the control group $(0 \mathrm{U} / \mathrm{mL}$ IFN- $\gamma)$, so that decreased MTT reduction levels became an indication of cell injury. Fig. (4) indicates that MTT reduction levels decreased dosedependently, with 25 and $125 \mathrm{U} / \mathrm{mL}$ IFN- $\gamma$ inhibiting MTT reduction, compared to the control group, by $16.52 \%$ and $19.85 \%$, respectively.

After identifying $25 \mathrm{U} / \mathrm{mL}$ as a suitable concentration of IFN- $\gamma$ for the experiment, $25 \mathrm{U} / \mathrm{mL}$ IFN- $\gamma$ induced HaCAT cells were treated with $12.5-50 \mu \mathrm{g} / \mathrm{mL}$ AF-FD for $72 \mathrm{~h}$ to examine the effect of AF-FD on MTT reduction. AF-FD at the concentrations of $12.5,25$, and $50 \mu \mathrm{g} / \mathrm{mL}$ reversed the inhibitory effect of $25 \mathrm{U} / \mathrm{mL}$ IFN- $\gamma$ on MTT reduction in a dose-dependent manner. Besides, the increase of MTT reduction levels in $25-50 \mu \mathrm{g} / \mathrm{mL}$ AF-FD groups was statistically significant, compared with the MTT reduction level in $25 \mathrm{U} / \mathrm{mL}$ IFN- $\gamma(0 \mu \mathrm{g} / \mathrm{mL}$ AF-FD) group $(P<0.05)$ (Fig. 5).
Table 2. Quantitation of the Reference Substance and Total Flavonoids in Ten Replicate Samples of AF-FD

\begin{tabular}{|c|c|c|}
\hline \multirow{2}{*}{ Sample } & \multicolumn{2}{|c|}{ Percentage (\%) } \\
\cline { 2 - 3 } & Reference Substance & Total Flavonoids \\
\hline \hline 1 & 3.172 & 55.64 \\
\hline 2 & 3.225 & 56.30 \\
\hline 3 & 3.531 & 57.21 \\
\hline 4 & 3.003 & 55.42 \\
\hline 5 & 3.483 & 56.06 \\
\hline 6 & 3.016 & 54.33 \\
\hline 7 & 4.036 & 55.01 \\
\hline 8 & 4.169 & 53.96 \\
\hline 9 & 3.142 & 55.33 \\
\hline 10 & 3.659 & 54.69 \\
\hline
\end{tabular}

Notes: Quantitation of the reference substance in AF-FD was performed by LC-2010 HPLC. The content of total flavonoids in AF-FD was determined by UV-1601 spectrophotometry using an external standard method.

\section{The Active Fraction of Flos Daturae (AF-FD) Decreased LDH Leakage Induced by IFN- $\gamma$ in HaCAT Cells}

The LDH leakage assay was performed in a similar manner to the MTT reduction assay. The data from all experiments were normalized to the LDH leakage level of the control group. In HaCAT cells, IFN- $\gamma(0-125 \mathrm{U} / \mathrm{mL})$ increased LDH leakage in a dose dependent manner. The 25 and 125 $\mathrm{U} / \mathrm{mL}$ IFN- $\gamma$ treated groups were significantly different from the control, with LDH leakage increased by $14.85 \%$ and $27.48 \%$, respectively (Fig. 6A).

Fig. (6B) shows a significant increase in LDH leakage level between the control group and the $25 \mathrm{U} / \mathrm{mL}$ IFN- $\gamma(0$ $\mu \mathrm{g} / \mathrm{mL}$ AF-FD) group, indicating that $25 \mathrm{U} / \mathrm{mL}$ IFN- $\gamma$ can

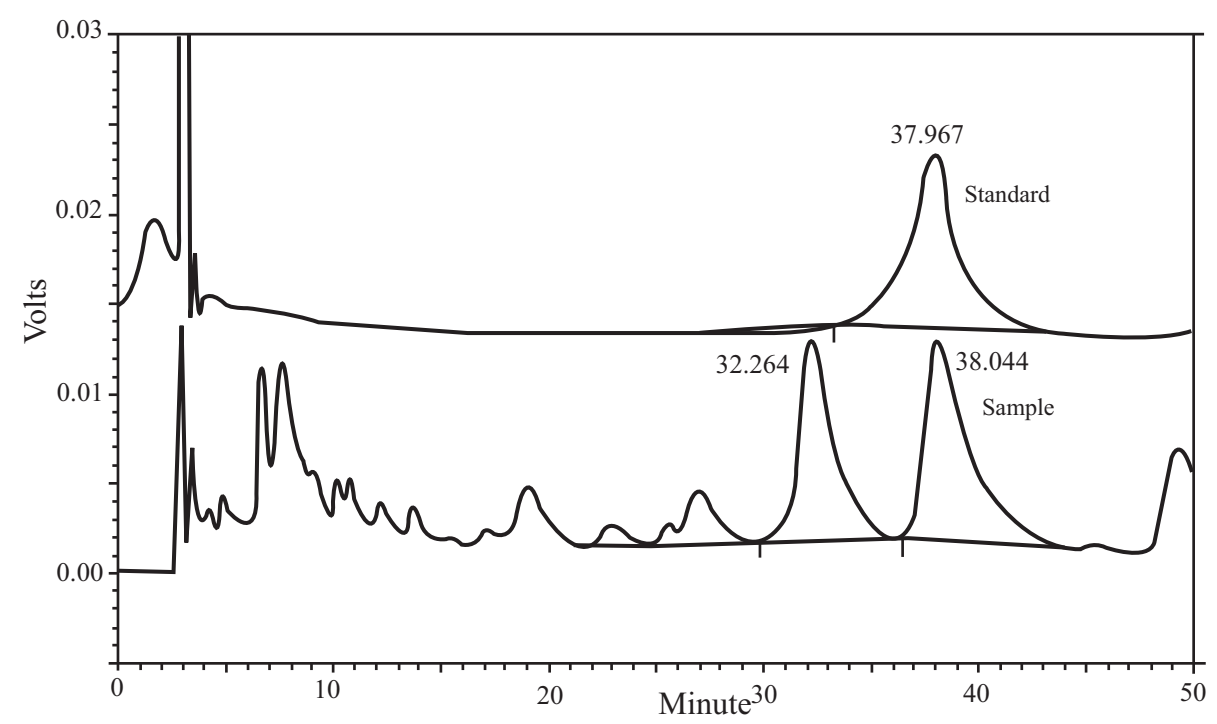

Fig. (2). HPLC Chromatogram of standard and active fraction sample. HPLC analysis of reference substance and methanol solution of AFFD was completed by LC-2010 HPLC. Mobile Phase: MeOH/Buffer=2:98. Column: Hypersil ODS2 $5 \mu \mathrm{m} 4.6 \mathrm{~mm} \times 250 \mathrm{~mm}$. Detection wavelength: $268 \mathrm{~nm}$. Column temperature: $30^{\circ} \mathrm{C}$. Flow rate: $1 \mathrm{~mL} / \mathrm{min}$. 


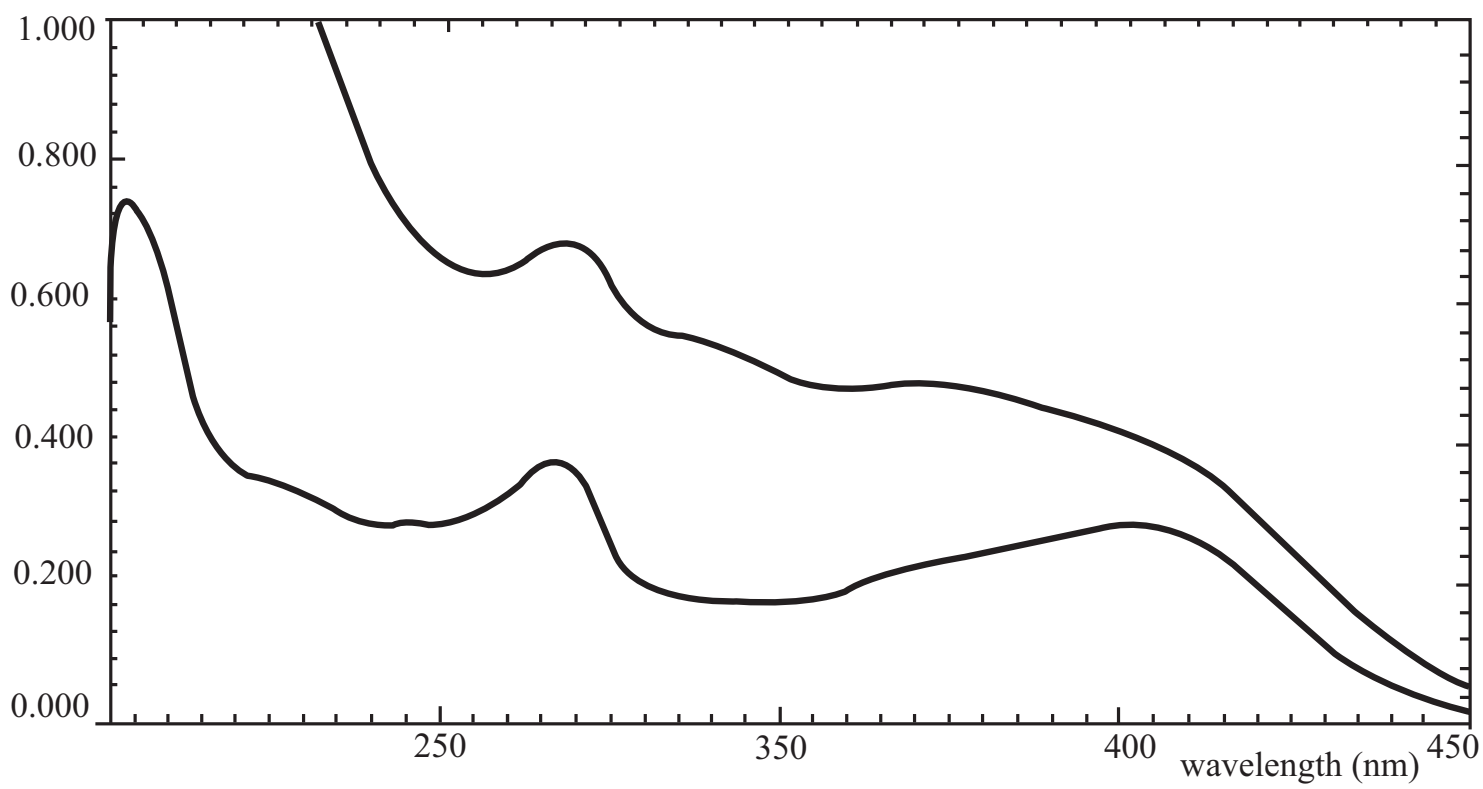

Fig. (3). UV Chromatogram of standard and active fraction sample solution. UV analysis of total flavonoids in the reference substance and AF-FD was performed with UV-1601 spectrophotometry. Based on these results, a detection wavelength of $268 \mathrm{~nm}$ was established.

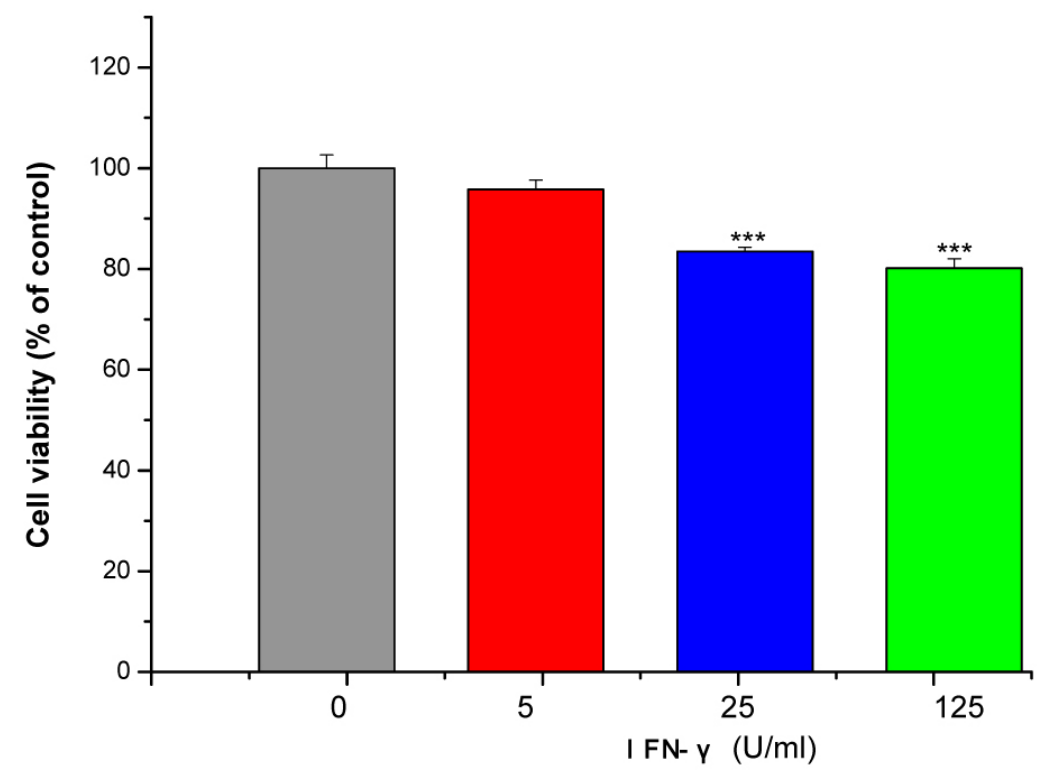

Fig. (4). Effect of IFN- $\gamma$ on viability of HaCAT cells. HaCAT cells were treated with IFN- $\gamma$ at different concentrations. Cell viability was assessed by MTT assay (mean \pm S.E., $\mathrm{n}=4,{ }^{* * *} P<0.001$ compared with control).

significantly raise LDH leakage in HaCAT cells. Treatment with AF-FD (12.5-50 $\mu \mathrm{g} / \mathrm{mL})$ attenuated the LDH leakage induced by IFN- $\gamma(25 \mathrm{U} / \mathrm{mL})$ dose- dependently. The effect of the 25 and $50 \mu \mathrm{g} / \mathrm{mL}$ AF-FD treatments were statistically significant $(P<0.05)$.

\section{Effect of the Active Fraction of Flos Daturae (AF-FD) on IFN- $\gamma$-induced Apoptosis in HaCAT Cells}

FCM and the Hoechst 33342 assay were implemented to determine the apoptosis rates induced by INF- $\gamma$ and the effect of AF-FD on this induced apoptosis. Fig. (7A) and (7B) show data obtained from FCM. A dramatic increase in apoptosis was observed in the $25 \mathrm{U} / \mathrm{mL}$ IFN- $\gamma(0 \mu \mathrm{g} / \mathrm{mL}$ AF-FD $)$ treatment as compared with the control group. Accordingly
AF-FD (12.5-50 $\mu \mathrm{g} / \mathrm{mL})$ inhibited apoptosis at concentrations of 25 and $50 \mu \mathrm{g} / \mathrm{mL}$.

Apoptosis rates were also quantified by Hoechst 33342 staining of HaCAT cells (Fig. 7C). The apoptosis rate of the control group was $0.68 \% \pm 0.17$. Treatment with $25 \mathrm{U} / \mathrm{mL}$ IFN- $\gamma(0 \mu \mathrm{g} / \mathrm{mL}$ AF-FD) increased the rate to $7.9 \%$. Contrarily, $25 \mu \mathrm{g} / \mathrm{mL}$ AF-FD reduced IFN- $\gamma$ induced apoptosis to $3.5 \%$.

With Hoechst 33342 staining, the nuclei of normal HaCAT cells exhibited diffuse uniform fluorescence, while the nuclei of apoptotic cells were heavily stained and exhibited dense granular fluorescence or fluorescent debris (see Fig. 7D). 


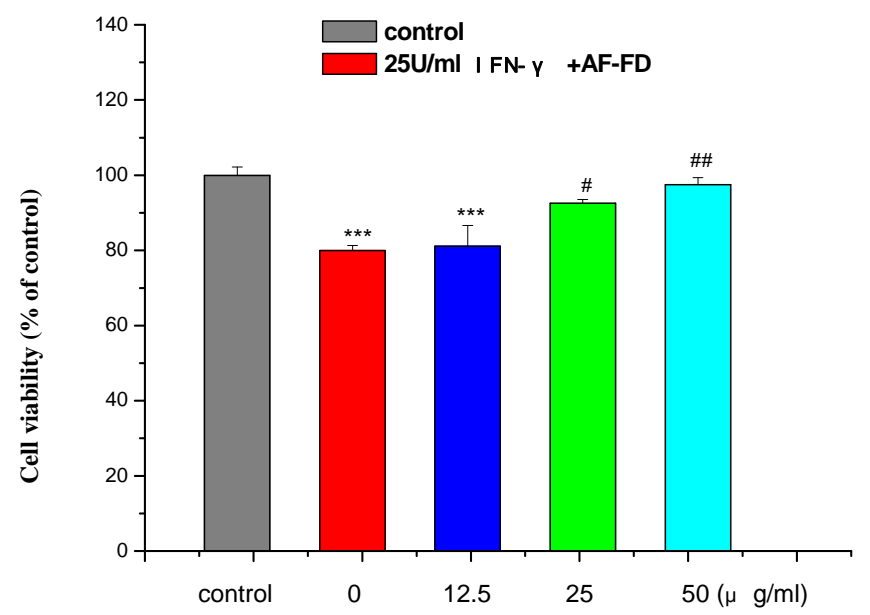

Fig. (5). Effect of AF-FD on the inhibition of MTT reduction induced by IFN- $\gamma$ in HaCAT cells. HaCAT cells were treated with AF-FD $(12.5-50 \mu \mathrm{g} / \mathrm{mL})$ and $25 \mathrm{U} / \mathrm{mL}$ IFN- $\gamma$ at $37^{\circ} \mathrm{C}$ for $72 \mathrm{~h}$. Cell viability was assessed by MTT assay. (mean \pm S.E., $\mathrm{n}=4,{ }^{* * *} P$ $<0.001$ compared with control; ${ }^{\#} P<0.05$, ${ }^{\#} P<0.01$ compared with the treatment of $0 \mu \mathrm{g} / \mathrm{mL}$ ).

\section{Effect of the Active Fraction of Flos Daturae (AF-FD) on IFN- $\gamma$-induced Over-expression of K 17 in HaCAT Cells}

Western blotting was used to assay the expression of $\mathrm{K} 17$. By measuring the optical density in the same experimental design described for FCM testing, the expression of K17 was quantified under the influence of IFN- $\gamma$ and AFFD. To facilitate the analysis, all experimental data were normalized to the control group.

A significant increase in optical density was observed in the $25 \mathrm{U} / \mathrm{mL}$ IFN- $\gamma(0 \mu \mathrm{g} / \mathrm{mL}$ AF-FD $)$ group, indicating that $25 \mathrm{U} / \mathrm{mL}$ IFN- $\gamma$ can remarkably raise $\mathrm{K} 17$ expression in HaCAT cells. K17 expression was reduced in the presence of AF-FD. This reduction in K17 expression was statistically significant in the $25-50 \mu \mathrm{g} / \mathrm{mL}$ AF-FD groups as compared to the $25 \mathrm{U} / \mathrm{mL} \mathrm{IFN-} \gamma(0 \mu \mathrm{g} / \mathrm{mL}$ AF-FD) group $(P<0.05)$ (Fig. 8).

\section{DISCUSSION}

Clinical reports in the latter 20th century have identified IFN- $\gamma$ as one of the essential etiopathogenesis agents in the induction and aggravation of psoriasis [27]. In cell culture experiments, IFN- $\gamma$ induced cell damage in HaCAT cells, derived from human skin, is one widely accepted cellular model of psoriasis. Böckelmann and coworkers consider this model reliable and credible in psoriasis research [19] and it was used in this investigation. MTT and LDH assays were implemented in this study to examine the effect of INF- $\gamma$ on HaCAT cells. The MTT assay measures the reduction of MTT to formazan by mitochondria and is dependent upon the integrity and viability of cells, while the LDH assay measures the release of the intracellular enzyme LDH upon damage to the plasma membrane. Data from this investigation indicated that treatment with 25 and $125 \mathrm{U} / \mathrm{mL}$ IFN- $\gamma$ resulted in a significant decline in MTT reduction, and notably increased LDH leakage. In other words, INF- $\gamma$ not only inhibited the function of mitochondria, but also damaged the integrity of the cell membrane. These results were consistent with a previous study on IFN- $\gamma$ induced cell injury [19]. Al-
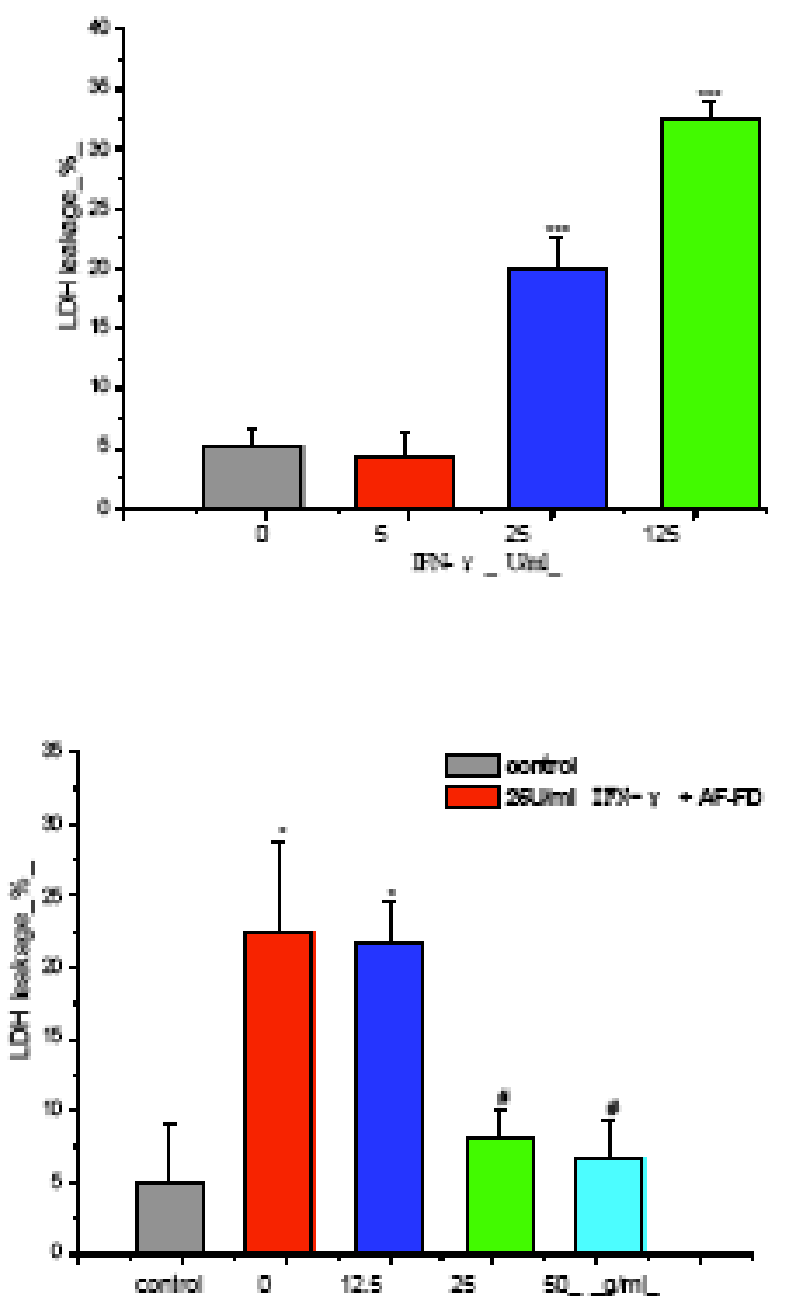

Fig. (6). Effect of AF-FD on IFN- $\gamma$-induced LDH leakage in HaCAT cells. A: LDH leakage of HaCAT cells treated with 5-125 $\mathrm{U} / \mathrm{mL}$ IFN- $\gamma$ for $72 \mathrm{~h}$ was measured; B: HaCAT cells were treated with $25 \mathrm{U} / \mathrm{mL}$ IFN- $\gamma$ in the absence or presence of AF-FD (12.5-50 $\mu \mathrm{g} / \mathrm{mL}$ ) for $72 \mathrm{~h}$ (mean \pm S.E., $\mathrm{n}=4,{ }^{*} P<0.05,{ }^{* * *} P<0.001 \mathrm{com}-$ pared with control; ${ }^{\#} P<0.05$ compared with the treatment of 0 $\mu \mathrm{g} / \mathrm{mL})$.

though AF-FD has been clinically used as a favorable psoriasis treatment, its mechanism of action was previously unknown. In this study we explored the effects of AF-FD in the IFN- $\gamma$ induced HaCAT cell model. Data revealed that 12.5$50 \mu \mathrm{g} / \mathrm{mL}$ AF-FD could dose-dependently reverse the inhibition of MTT reduction and reduce LDH leakage in HaCAT cells treated with IFN- $\gamma$, which, considering the nature of the MTT assay and the LDH assay, lead to the conclusion that AF-FD is capable of maintaining the biological activity of mitochondria and the integrity of the cell membrane. In addition, in the MTT assay data (Fig. 4), 25 and $125 \mathrm{U} / \mathrm{ml}$ IFN- $\gamma$ does not produce impressive difference. However, the dose dependant response in LDH assay (Fig. 6A) is very much prominent in higher IFN concentration. The distinct difference between IFN dose dependant sensitivity of MTT and LDH assay may indicate differential toxicity mechanism.

The relationship between psoriasis and cell apoptosis has aroused concern for decades. Coldsmith [28] suggested that the accumulation of unnecessary cells and the thickening of 

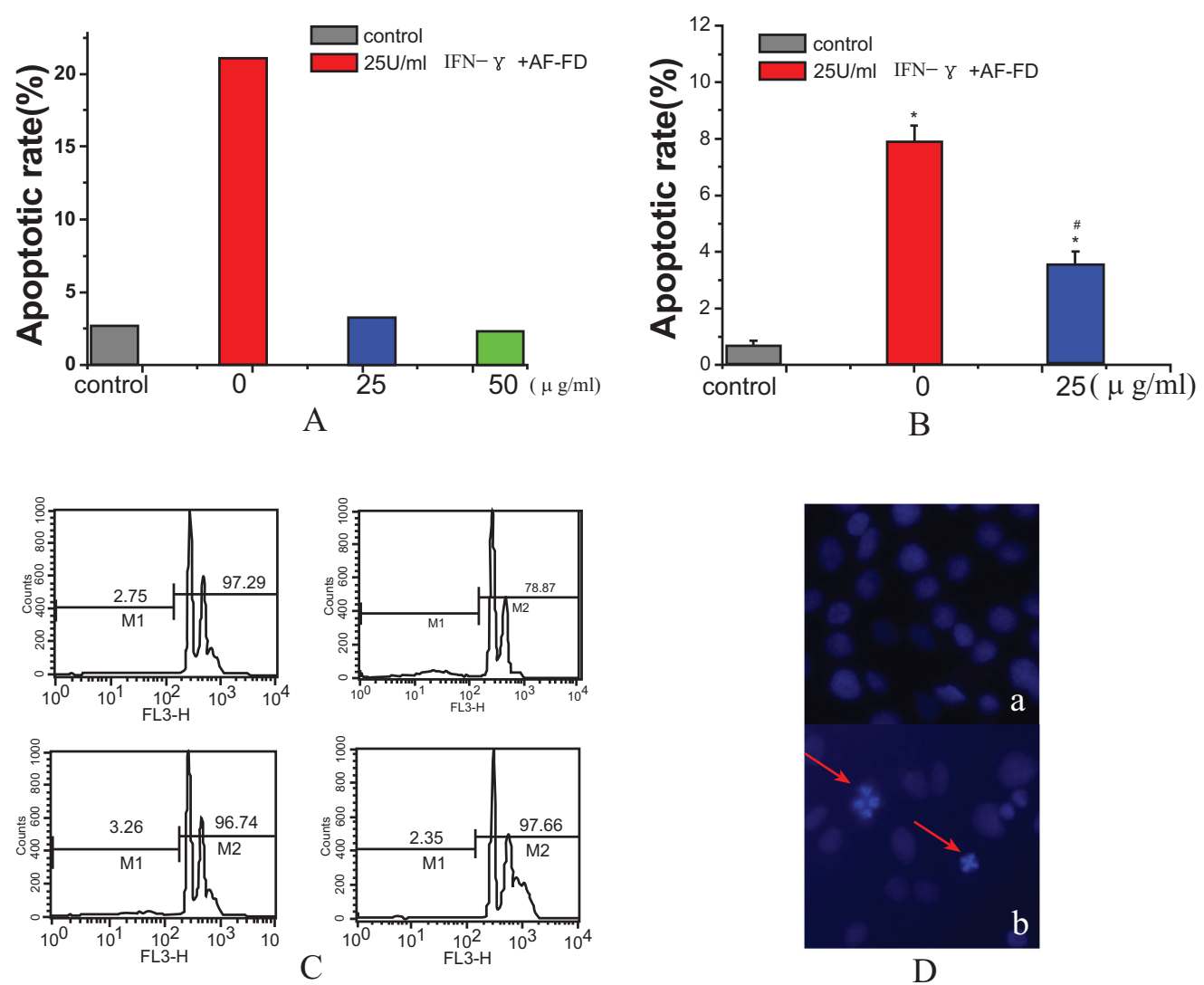

Fig. (7). Effect of AF-FD on IFN- $\gamma$-induced apoptosis in HaCAT cells. A. Protective effects of AF-FD on IFN- $\gamma$-induced apoptosis. HaCAT cells were treated with AF-FD $(12.5-50 \mu \mathrm{g} / \mathrm{mL})$ and $25 \mathrm{U} / \mathrm{mL}$ IFN- $\gamma$ at $37^{\circ} \mathrm{C}$ for $72 \mathrm{~h}$. Cell apoptosis was assessed by FACS-can test. All experiments were performed in triplicate, with the mean of the three replicates shown. B. Antagonistic effect of AF-FD on IFN- $\gamma$-induced apoptosis was assessed by Hoechst 33342 staining. HaCAT cells were treated with $25 \mathrm{U} / \mathrm{mL}$ IFN- $\gamma$ in the absence or presence of $25 \mu \mathrm{g} / \mathrm{mL}$ AF-FD for $72 \mathrm{~h}$, then the cell apoptotic rate was calculated (mean $\pm \mathrm{S} . \mathrm{E}, \mathrm{n}=4,{ }^{* *} P<0.01$ compared with control; ${ }^{\# \#} P<0.01 \mathrm{compared}$ with the treatment of $0 \mu \mathrm{g} / \mathrm{mL}$ ). C. Effect of AF-FD on IFN- $\gamma$-induced apoptosis in HaCaT cell. a: Control cells; b: Cells were treated with $25 \mathrm{U} / \mathrm{mL}$ IFN- $\gamma$; c-d: Cells were exposed to AF-FD $(25-50 \mu \mathrm{g} / \mathrm{mL})$ and $25 \mathrm{U} / \mathrm{mL}$ IFN- $\gamma$. Experiments were performedin triplicate. D. IFN- $\gamma(25$ $\mathrm{U} / \mathrm{mL}$ )-induced apoptosis in HaCAT cells was assessed by Hoechst 33342 staining. a: Control group; b: Cells were exposed to $25 \mathrm{U} / \mathrm{mL}$ IFN- $\gamma$ for $72 \mathrm{~h}$. Arrows indicate dead cells with apoptotic nuclei $(\times 400)$.

the corneum, caused by decreased apoptosis of malpighian cells, are involved inthe pathogenesis of psoriasis. Weedon [29] speculated that the hyper-apoptosis of malpighian cells maybe the cause of hyperplasia in psoriasis. Later research has supported the latter conclusion [30,31]. In this study, we used Hoechst 33342 staining and flow cytometry to assay IFN- $\gamma$ induced apoptosis in HaCAT cells. Dose-dependent elevation in the apoptosis rate was observed with both methods. This outcome further supports the hypothesis that excessive apoptosis is the cause of psoriasis. The effect of AFFD on IFN- $\gamma$ induced apoptosis was also examined. Data showed that $12.5-50 \mu \mathrm{g} / \mathrm{mL}$ AF-FD significantly reduced the apoptosis rate increased by IFN- $\gamma$. The role of AF-FD in the abatement of hyper-apoptosis in psoriasis may explain the treatment effect of AF-FD in clinical practice.

K17, which is rarely expressed in normal skin, can be significantly expressed in psoriatic lesions, with certain relevance to the process and severity of the disease. Recent study [32] has recognized a $\mathrm{K} 17 / \mathrm{IFN}-\gamma$ autoimmune loop as the etiopathogenesis mechanism in the process of psoriasis. IFN- $\gamma$, one of the key cytokines secreted by $\mathrm{T}$ cells, can induce the expression of K17, and K17 can, in return, stimu- late the activation and proliferation of $\mathrm{T}$ cell, which forms the mutual promotion loop between K17 and T cells. The sustained activation of $\mathrm{T}$ cells and the hyper-expression of $\mathrm{K} 17$ lead to an autoimmune reaction against K17, which may play a key role in the maintenance, increase, chronicity and recurrence of psoriasis. Thus it has been proposed [32] that the expression of K17 could be used as index of the disease severity and effects of treatment of psoriasis. In this study Western blotting was used to quantify the expression of K17. Results indicated that IFN- $\gamma$ could increase the expression of $\mathrm{K} 17$ in HaCAT cells in a dose-dependent manner. Combined with the increased apoptosis rates of HaCAT cells induced by IFN- $\gamma$, as revealed byHoechst 33342 staining and flow cytometry, the experimental data suggest that the over- expression of K17 in the surface of membrane occurs during apoptosis. Furthermore, a decrease in the expression of K17 resulted from the addition of AF-FD (12.5-50 $\mu \mathrm{g} / \mathrm{mL})$ o IFN$\gamma$ induced HaCAT cells, revealing the inhibitory effect of AF-FD on K17expression, and supporting the strong relationship between K17 expression and apoptosis. Considering the role played by K17 in the pathology of psoriasis, we propose $\mathrm{K} 17$ as a new drug target in the treatment of psoriasis based on the present study. Moreover two main components, 


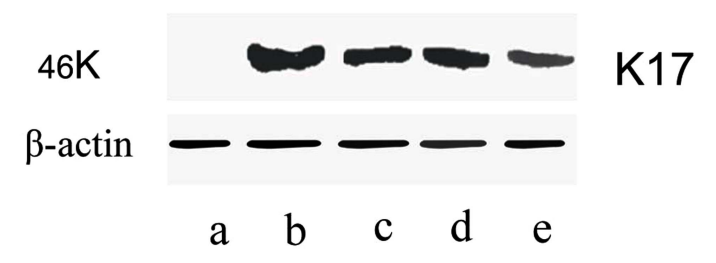

$\mathbf{A}$

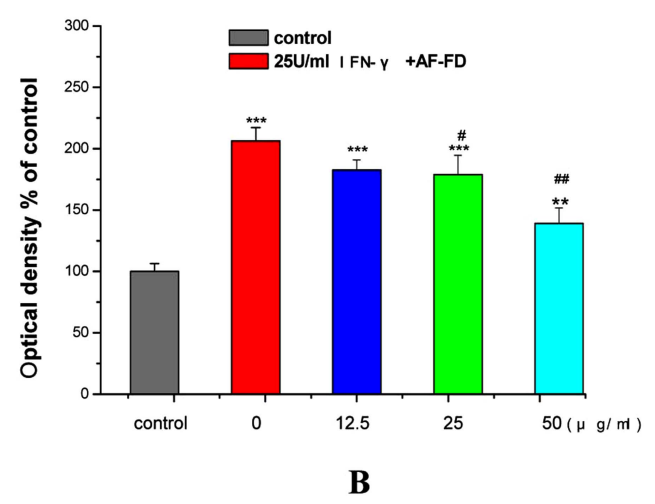

Fig. (8). Effect of AF-FD on IFN- $\gamma$-induced over-expression of K 17 in HaCAT cells. HaCAT cells were treated with $25 \mathrm{U} / \mathrm{mL}$ IFN- $\gamma$ in the absence or presence of AF-FD (12.5- $50 \mu \mathrm{g} / \mathrm{mL}$ ) for $72 \mathrm{~h}$. The AF-FD treatments (12.5- $50 \mu \mathrm{g} / \mathrm{mL}$ ) were compared with $0 \mu \mathrm{g} / \mathrm{mL} \mathrm{AF-FD}$ group and the control group. K17 was separated by SDS-PAGE and immunoblotted with an anti-cytokeratin 17 multiclonal antibody. A. a: Control group; b: $0 \mu \mathrm{g} / \mathrm{mL}$ AF-FD (25 U/mL IFN- $\gamma$ ) group; c: $12.5 \mu \mathrm{g} / \mathrm{mL}$ AF-FD (25 U/mL IFN- $\gamma$ ) group; d: $25 \mu \mathrm{g} / \mathrm{mL}$ AF-FD $(25 \mathrm{U} / \mathrm{mL}$

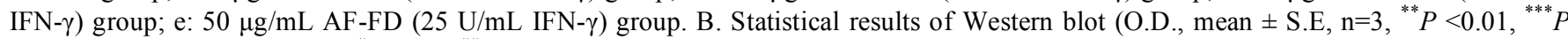
$<0.001$ compared with control; ${ }^{\#} P<0.05,{ }^{\#} P<0.01$ compared with the treatment of $0 \mu \mathrm{g} / \mathrm{mL}$ ).

flavonoids and withanolides constituents, have been separated from AF-FD. Further experiments are required to determine which of these fractions possesses psoriasisprotective properties.

\section{CONCLUSIONS}

To summarize, for the first time the protective effects of the active fraction of Flos Daturae (AF-FD) against IFN- $\gamma$ induced apoptosis in the HaCAT cell model have been demonstrated. Furthermore, experimental data in this study also showed that AF-FD can reduce the hyper-expression of K17 induced by IFN- $\gamma$.

\section{ACKNOWLEDGEMENTS}

This work was funded by the Major State Basic Research Development Program of China (973 Program 2006CB504708) and the National Natural Science Foundation of China (No.30371736, 30672633). The authors thank Prof. Jian-hui Liang in the National Institute on Drug Dependence of Peking University for the generous gift and useful discussions concerning the statistical analysis of the data.

\section{ABBREVIATIONS}

$\begin{array}{ll}\text { AF-FD } & =\text { Active fraction of Flos Daturae } \\ \text { CCTCC } & =\text { China Center for Type Culture Collection } \\ \text { FBS } & =\text { Fetal bovine serum }\end{array}$

FC-FD $=$ Total flavonoids in the active fraction of Flos Daturae

$\begin{array}{ll}\text { FCM } & =\text { Flow cytometry } \\ \text { FDA } & =\text { U.S. Food and Drug Administration } \\ \text { HaCAT } & =\text { Human keratinocyte cell line } \\ \text { IFN- } \gamma & =\text { Interferon-gamma } \\ \text { K17 } & =\text { keratin } 17 \\ \text { LDH } & =\text { Lactate dehydrogenase } \\ \text { MDHA } & =\text { Mitochondrial dehydrogenase activity } \\ \text { MEM } & =\text { Minimum essential medium } \\ \text { MTT } & =\text { Thiazolyl blue tetrazolium bromide } \\ \text { O.D } & =\text { Optical density } \\ \text { PBS } & =\text { Phosphate-buffered saline } \\ \text { RNase A } & =\text { Ribonuclease A } \\ \text { SDS } & =\text { Sodium dodecyl sulfate } \\ \text { T cell } & =\text { T lymphocytes }\end{array}$

\section{REFERENCES}

[1] Mehlis, S. L.; Gordon, K. B. The immunology of psoriasis and biologic immunotherapy. J. Am. Acad. Dermatol., 2003, 49 (2 suppl), S44-50.

[2] Weinberg, J. M. An overview of infliximab, etanercept, efalizumab, and alefacept as biologic therapy for psoriasis. Clin. Ther., 2003, 25, 2487-2505. 
[3] Barker, J. N. W. N.; Karabin, G. D.; Stoof, T. J.; Sarma, V. J.; Dixit, V. M.; Nickoloff, B. J. Detection of interferon-gamma mRNA in psoriatic epidermis by polymerase chain reaction. $J$. Dermatol. Sci., 1991, 2, 106-111.

[4] Moll, R.; Franke, W. W.; Schiller, D. L. The catalog of human cytokeratins: Patterns of expression in normal epithelia, tumors and cultured cells. Cell, 1982, 31, 11-24.

[5] De Jong, E. M. G. J.; van Vlijmen, I. M. M. J.; van Erp, P. E. J.; Ramaekers, F. C. S.; Troyanowski, S. M.; van de Kerkhof, P. C. M. Keratin 17: A useful marker in anti-psoriatic therapies. Arch. Dermatol. Res., 1991, 283, 480-482.

[6] Flohr, T.; Buwitt, U.; Bonnekoh, B.; Decker, T.; Bottger, E. C. Interferongamma regulates expression of a novel keratin class I gene. Eur. J. Immunol., 1992, 22, 975-979.

[7] Bonnekoh, B.; Huerkamp, C.; Wevers, A.; Geisel, J.; Sebok, B.; Bange, F. C.; Greenhalgh, D. A.; Bottger, E. C.; Krieg, T.; Mahrle, G. Up-regulation of keratin 17 expression in human HaCAT keratinocytes by interferon- $\gamma$. J. Invest. Dermatol., 1995, 104, 58-61.

[8] Bonnekoh, B.; Bockelmann, R.; Ambach, A.; Gollnick, H. Dithranol and dimethylfumarate suppress the interferon-gamma-induced up-regulation of cytokeratin 17 as a putative psoriasis autoantigen in-vitro. Skin Pharmacol. Appl. Skin Physiol., 2001, 14, 217-225.

[9] Kreuter, A.; Sommer, A.; Hyun, J. 1\% Pimecrolimus, 0.005\% calcipotriol, and $0.1 \%$ betamethasone in the treatment of intertriginous psoriasis: a double-blind, randomized controlled study. Dermatology, 2006, 142(9), 1138-1143.

[10] Tzung, T. Y.; Wu, J. C.; Hsu, N. J. Comparison of tazarotene $0.1 \%$ gel plus petrolatum once daily versus calcipotriol $0.005 \%$ ointment twice daily in the treatment of plaque psoriasis. Acta Derm.Venereol., 2005, 85(3), 236-239.

[11] Baker, B. S.; Powles, A. V.; Savage, C. R. ntralesional clycosporin in psoriasis: effectson T lymphocyte and dendritic cell subpopulations. Br. J. Dermatol., 1989, 120, 207.

[12] Kopp, T.; Karlhofer, F.; Szepfalusi, Z. Successful use of acitretin in conjunction with narrowband ultraviolet B phototherapy in a child with severe pustular psoriasis, von Zumbusch type. Br. J. Dermatol., 2004, 151(4), 912-916.

[13] Liu, H. J.; Ouyang, H.; Yang, Z. B. The effects of Xian-fang-xiao$y$ in tablet on the plasma endothelin-1 and calcitonin gene related peptide of psoriasis. Chin. J. Lepr.Skin Dis., 2005, 12(1), 13-15.

[14] Xiang, Y. P.; Chen, J. G.; Yang, Z. B. Effects of Zhuhuang Granule-II on the detection of MMP-2 and TIMP-2 in lesions of psoriasis vulgaris. Chin. J. Derm.-Venerol., 2004, 18(11), 662-664.

[15] Gottlieb, A. B.; Leonardi, C. L.; Goffe, B. S. Etanercept monotherapy in patients with psoriasis: a summary of safety, based on an integrated multistudy database. J. Am. Acad. Dermatol., 2006, 54(3), 92-100.

[16] Papp, K. A.; Bressinck, R.; Fretzin, S. Safety of efalizumab in adults with chronic moderate to severe plaque psoriasis: A phaseb, randomized, controlled trial. Int. J. Dermatol., 2006, 45(5), 605614.

[17] Tang, H. S.; Zhu, Y. Y. Advances of biologic agents in the treatment of psoriasis. J. Clin. Dermatol., 2007, 36(4), 2650267.

[18] Tang, L.; Wang, Q. H.; Yang, B. Y.; Xiao, H. B.; Sun, Y. P.; Kuang, H. X. Protective effects of active fraction and constituents from Flos Daturae on Chinese hamster ovary cells injuried by dimethyl sulfoxide. Chin. J. Trad. Herb. Drugs, 2006, 37(12), 18261831.

[19] Böckelmann, R.; Horn, T.; Gollnick, H.; Bonnekoh, B. Interferon$\gamma$-dependent in vitro medel for the putative keratin 17 autoimmune loop in psoriasis: exploration of pharmaco- and gene- therapeutic effects. Skin Pharmacol. Physiol., 2005, 18, 42-54.

[20] Yang, B. Y.; Wang, Q. H.; Xia, Y. G.; Feng, W. S.; Kuang, H. X. Withanolide compounds from the flower of Datura metel L. Helv. Chim. Acta 2007, 90, 1522-1528.

[21] Boukamp, P.; Petrussevska, R. T.; Breitkreutz, D.; Hornung, J.; Markham, A.; Fusenig, N. E. Normal keratinization in a spontaneously immortalized aneuploid human keratinocyte cell line. J. Cell Biol., 1988, 106, 761-771.

[22] Gautam, B.; Nishma, G.; Arun, K. Govindarajan, R. UV induced bystander signaling leading to apoptosis. Cancer Lett., 2005, 223 , 275-284.

[23] Hiroko, S.; Taketo, I.; Hirohiko, A.; Hiroyuki, O.; Takeshi, H. Effects of calcium concentration on the SOD activity and UVBinduced cytotoxicity in cultured human keratinocytes. Photodermatol. Photoimmunol. Photomed., 2005, 21, 9-14.

[24] Okada, T.; Tanaka, K.; Nakatani, F.; Sakimura, R.; Matsunobu, T.; Li, X.; Hanada, M.; Nakamura, T.; Oda, Y.; Tsuneyoshi, M.; Iwamoto, Y. Involvement of P-glycoprotein and MRP1 in resistance to cyclic tetrapeptide subfamily of histone deacetylase inhibitors in the dr $\mu$ g-resistant osteosarcoma and Ewing's sarcoma cells. Int. J. Cancer, 2006, 118, 90-97.

[25] Chen, Z. Z.; Xu, R. X.; Jiang, X. D.; Teng, X. H.; Li, G. T.; Zhou, Y. X. Lack of telomerase activity in rabbit bone marrow stromal cells during differentiation along neural pathway. Chin. J. Traumatol., 2006, 9, 201-205.

[26] Laemmli, U. K. Cleavage of structural proteins during the assembly of the head of bacteriophage T4. Nature, 1970, 227, 680-685.

[27] Chen, S. H.; Arany, I.; Apisarnthanarax, N.; Rajaraman, S.; Tyring, S. K.; Horikoshi, T.; Brysk, H.; Brysk, M. M. Response of keratinocytes from normal and psoriatic epidermis to interferon- $\Gamma$ differs in the expression of zinc- $\alpha 2$-glycoprotein and cathepsin D. FASEB J., 2000, 14(3), 565-571.

[28] Chuong, C.M.; Nickoloff, B.J.; Elias, P.M.; Goldsmith, L.A.; Macher, E.; Maderson, P.A.; Sundberg, J.P.; Tagami, H.; Plonka, P.M.; Thestrup-Pederson, K.; Bernard, B.A.; Schröder, J.M.; Dotto, P.; Chang, C.M.; Williams, M.L.; Feingold, K.R.; King, L.E.; Kligman, A.M.; Rees, J.L.; Christophers, E. What is the 'true' function of skin? Exp Dermatol., 2002, 11(2), 159-87.

[29] Weedon, D. Apoptosis. Adv. Dermatol., 1990, 5, 243-254.

[30] Xu, J.; Jia, S. W.; Zhong, Q. L.; Yang, H. Q.; Zheng, M. R.; Gu, J. Study on cell apoptosis in psoriasis. South. Chin. J. Dermatol.Venerol., 2004, 11 (2), 91-100.

[31] Bianchi, L.; Farrace, M. C.; Nini, G. Abnormal bci-2 and "Tissue" transglutaminasa expression in psoriatic skin. J. Invest. Dermatol., 1994, 103, 829-833.

[32] Bockelmann, R.; Horn, T.; Gollnick, H.; Bonnekoh, B. Interferongamma-dependent in vitro model for the putative keratin 17 autoimmune loop in psoriasis: exploration of pharmaco- and genetherapeutic effects. Skin Pharmacol Physiol., 2005, 18(1), 42-54.

Received: July 30, 2010

Revised: April 18, 2011

Accepted: April 21, 2011

(C) Tang et al.; Licensee Bentham Open.

This is an open access article licensed under the terms of the Creative Commons Attribution Non-Commercial License (http:/creativecommons.org/ licenses/ by-nc/3.0/) which permits unrestricted, non-commercial use, distribution and reproduction in any medium, provided the work is properly cited. 